\title{
Evidensbaseret praksis i videnskabsteoretisk belysning ${ }^{1}$
}

\author{
Af Birger Hjørland
}

\begin{abstract}
Evidensbaseret praksis er en ca. 20 år gammel tvaerfaglig bevagelse, der stammer fra medicin. Den er af betydelig interesse for biblioteks- og informationsvidenskab, fordi den fokuserer på en grundig dokumentation af det beslutningsgrundlag, der er etableret i forskningen, og på en optimering af alle led $i$ dokumentations- og søgeprocesserne. Evidensbaseret praksis er imidlertid også en kontroversiel bevagelse, iscer i bløde områder som psykologi, sygepleje og biblioteks- dokumentations- og informationsfaget (BDI), men også inden for medicin selv. Hovedkritikken går dels på, at praktikere fratages deres autonomi og på, at forståelsen for grundlceggende årsagsmekanismer svakkes. Denne videnskabsteoretiske kritik er ikke blot relevant for praktiseringen affx evidensbaseret medicin, men også for BDIs forhold til dokumentationsprocesser generelt. Artiklen prcesenterer og undersøger disse videnskabsteoretiske problemer. Selvom det er vigtigt at forholde sig åbent over for forskelle mellem forskellige domoener, er det iscer inden for medicin de principielle spørgsmål, der er relevante for hele EBP-bevagelsen, kan analyseres mest dybtgående. Dette skyldes, at de problemer, der er i evidensbaseret praksis i det relativt hårde medicinske område, gør sig endnu mere galdende i blødere områder. Derfor koncentrerer denne artikel sig mest om evidensbaseret medicin (EBM).
\end{abstract}

Birger Hjørland er cand.psych., fil.dr og professor ved Det Informationsvidenskabelige Akademi. bh@iva.dk

\section{Indledning}

Evidensbaseret praksis (fra engelsk: "evidence based practice"), EBP, er en bevægelse, der går tilbage til 1980'erne med udgangspunkt i medicinsk forskning og praksis under betegnelsen evidensbaseret medicin (engelsk: "evidence based medicine"). I denne artikel anvender vi betegnelsen EBM når det handler om medicinsk praksis og EBP, når det handler om evidensbaseret praksis i andre fag eller om bevægelsen som en tværfaglig bevægelse. Det skal understreges, at EBP er baseret på ideologien og teknikken bag EBM, der kan føres tilbage til den engelske læge Archie L Cochrane, der i 1972 udgav bogen Effectiveness and Efficiency. Random Reflections on Health Services. EBM fik sit gennembrud med en artikel i det medicinske tidsskrift JAMA (The Journal of the American Medical Association) i 1992 (Evidence-based medicine working group, 1992). Siden har bevægelsen vokset $\mathrm{i}$ indflydelse og som sagt også bredt sig til andre fag, herunder til psykologi, sygepleje, pædagogik og biblioteks- og informationsvidenskab ${ }^{2}$.

Da de videnskabsteoretiske problemstillinger overordnet er de samme, vil denne artikel fokusere på EBM, hvor den mest dybtgående diskussion har fundet sted ${ }^{3}$. Den forskel, der er mellem fagområder fremstilles ofte på den måde, at naturvidenskaber er hårdere end samfundsvidenskaber og derfor er mere egnede til formaliserede procedurer, $\mathrm{fx}$ bibliometri og EBP. Jeg har fravalgt en nærmere diskussion af EBP i psykologi, sygepleje og samfundsvidenskab, 
fordi en kritik her ville kunne afvises som en generel kritik af EBP og blot ses som et udtryk for, at nogle fag ikke er modne til EBP. Jeg har derfor fundet det vigtigt at gå til rødderne og tage den største udfordring op, at undersøge EBP på sin hjemmebane og $\mathrm{i}$ et relativt "hårdt" fag.

Da EBM tog sin begyndelse havde medicinsk praksis været forsknings- og videnskabsbaseret i langt over 100 år. Man kan blot tænke på Louis Pasteur (18221895), der havde betydelig succes i sit arbejde med udvikling af vaccinationer og sera mod sygdomme udløst af bakterieinfektioner. Der opstod hurtigt procedurer med at dokumentere og kommunikere videnskabelige resultater. Generelle medicinske tidsskrifter blev produceret fra slutningen af det 18.århundrede, mens specialiserede medicinske tidsskrifter udkom fra begyndelsen af det 20.århundrede. For at sikre højst mulig faglig standard indførte tidsskrifterne i det 20.århundrede fagfællebedømmelse. Surgeon General's Office udsendte sit første katalog i 1840 , og senere kom andre medicinske bibliografier og databaser, herunder MEDLINE. Medicinsk dokumentations- og informationsvidenskab har i dag udviklet sig til et vigtigt speciale med egne tidsskrifter.

Alle disse bestræbelser sigter imod at gøre medicinsk behandling forskningsbaseret og pålidelig ved at stille effektive redskaber til rådighed for at dokumentere og søge medicinsk viden. Det har naturligvis hele tiden været målet at optimere patientbehandlingen. Det har været ret indiskutabelt, at det handler om at finde de bedst mulige behandlingsprincipper således, at patienterne får den bedste behandling. Derfor har spørgsmålet med rette været rejst: Hvis evidensbaseret medicin udgør en ny strømning, et nyt "paradigme" eller en bestemt videnskabsteoretisk position, hvad var medicin da før 1980? Hvad står EBM i modsætning til ${ }^{5}$ ? Præcist det samme spørgsmål kan naturligvis rejses i de andre discipliner, hvortil EBPbevægelsen har bredt sig.

EBM og EBP indebærer en række teser, herunder:

- At beslutninger i praksis skal være baseret på "evidens"

- "Evidens" forstås som relevant forskningsbaseret viden ${ }^{6}$

- Dokumenteringen, indsamlingen og tolkningen af denne evidens skal foretages metodisk og kontrollabelt, den udgør videnskab på et metaniveau? .
- Resultatet af denne indsamling og tolkning bør publiceres som et "systematisk review"

- Der skal derfor udarbejdes eksplicitte normer for hvilke slags undersøgelser, der er mest relevante, og der opstilles et generelt hierarki over værdien af forskellige slags undersøgelser som evidens (jf. Carter, 2010).

Det nye i EBM rummer efter min opfattelse tre hovedaspekter:

- Et mere ukontroversielt aspekt, der går på en øget interesse for videnskabelig dokumentation.

- Et mere kontroversielt aspekt, der går på udbredelsen af en bestemt videnskabsteoretisk position (empiricisme $\mathrm{e}^{9}$ / positivisme), der står i modsætning til andre videnskabelige paradigmer, som herved undertrykkes.

- Et ændret forhold mellem videnskabsbaseret praksis og samfundets bureaukrati.

Denne artikel vil argumentere for, at den evidensbaserede interesse for dokumentation er en vigtig udvikling, især fra en BDI synsvinkel, da den vedrører de vidensorganiserende processer og systemer, der i mine øjne udgør kernen i informationsvidenskaben. På den anden side vil den argumentere for, at den empiristiske / positivistiske videnskabsideal i dag må anses som problematisk, hvorfor den må søges erstattet af en mere tidssvarende epistemologi. Dette gælder i særlig grad, når EBP anvendes i samfundsvidenskabelige og humanistiske sammenhænge. For det tredje vil jeg argumentere for, at den formalisering af videnskabeligheden, som EBP indebærer, kan risikere at medføre en svækkelse af videnskabens autonomi og dermed for kvaliteten af beslutningsgrundlaget.

\section{Evidensbaseret praksis som bevidsthed om og forskning i dokumentation}

Biblioteks-, dokumentations- og informationsvidenskab eller blot informationsvidenskab har i godt 100 år været defineret som videnskab med forskningsbaseret undervisning, videnskabelig publicering, videnskabelige konferencer, og hvad der hører til af formelle kriterier på at være en videnskabelig disciplin. Det er derfor forventeligt, at den biblioteksmæssige (og dokumentationsmæssige og informationsmæssige) praksis er forskningsbaseret, og at $i$ al fald en del af den forskningsmæssige viden, som praksis er 
baseret på, er produceret inden for informationsvidenskaben selv (mens dele hentes fra andre videnskaber). Mange af os har nok et uformelt indtryk af, at forbindelsen mellem forskning og praksis er alt for svag i BDI, og her kommer den evidensbaserede bevægelse som en velkommen ideologi, der - alt andet lige - kan være med til at styrke relationerne mellem teori og praksis.

Den evidensbaserede praksis bryder med informationsvidenskabelige traditioner, der fokuserer på brugerorienterede ${ }^{10}$ relevanskriterier, fordi den baserer sig på at undersøge forskningslitteraturens metoder og lægge disse til grund for dokumenters relevans, og hvordan denne bør synliggøres i faglige tidsskrifter og i bibliografiske databaser. For EBP er det vigtigt, hvordan givne påstande er underbyggede, fx om de er baseret på kliniske dobbeltblinde eksperimenter eller på andre metoder. Dette indebærer et syn på relevans, der har været næsten totalt negligeret i den informationsvidenskabelige litteratur om relevansbegrebet i al fald i de sidste 35 år (jf. Hjørland, 2010). EBM har ikke blot ført til en øget metodebevidsthed i medicinsk forskning, det har også ført til en øget bevidsthed om udformningen af videnskabelige artikler, udviklingen af strukturerede abstrakts, forbedring af indekseringen i databaser som MEDLINE, udarbejdelse af grundige manualer for medicinsk litteratursøgning (Higgins \& Green, 2009), interesse for og fokus på, hvordan man sammenfatter den eksisterende viden på et område (litteratursøgning, litteraturselektion, metareviews) m.v. Med andre ord har det styrket interessen for, bevidstheden om og beskæftigelsen med problemstillinger, der udgør kernen i BDI (men som delvis har været gledet ud af fagets fokus, jf. Hjørland, 2000). Frem for at fokusere på brugernes psykologi eller på systemernes brugergrænseflader mv., repræsenterer EBP en blandt flere nye strømninger i LIS, der primært fokuserer på dokumenter ${ }^{11}$, viden og dokumentation.

Det er i dag anerkendt, at den hastige udvikling, der sker inden for fx sundhedsfagene gør det nødvendigt at lave en systematisk vidensopsamling, og her tilbyder EBP en rationalisering i form af metaanalyser og en øget prioritering af de databaser, som kan levere den fornødne dokumentation. EBP fokuserer på processen med systematisk vidensindsamling og udarbejdelse af forskningsoversigter ("literature reviews", "systematic reviews"), som på en måde er eller bør være en selvfølge i enhver forskningsproces (og fx i specialeskrivning), men som ikke uden for EBP har været ofret en tilsvarende opmærksomhed, hvilket i øvrigt forekommer forbløffende ${ }^{12}$. Som alle andre forskningsområder er der imidlertid knyttet videnskabsteoretiske problemer også til videnskabelig dokumentation og metaanalyser, som det er hovedformålet med nærværende artikel at kaste lys over.

Jeg vil dog afslutte dette afsnit med at sige, at det jo er unægtelig er en styrkelse af BDI-faget når British Medical Journal i en - ganske vist satirisk - artikel (Clinicians for the Restoration of Autonomous Practice, 2002) opregner 10 bud, som skal opfyldes af EBM-principperne og i forbindelse med det ottende bud forlanger:

"Thou shalt ensure that all patients are seen by research librarians ${ }^{13}$ ",

\section{Evidensbaseret praksis som epistemologi}

Spørgsmålet om "den bedste evidens" er et videnskabsteoretisk problem

Evidensbaseret praksis betoner, at vores handlinger og beslutninger bør bygge på det bedst mulige beslutningsgrundlag, på den bedste videnskabelige evidens. Som sådan mener jeg, at det er et trivielt udsagn, som intet fornuftigt menneske kan være uenig i. Der er dog nogle fortalere for EBP, der opstiller alternativerne til EBP på en karikeret måde, som baseret på åbenbaringer, intuition, følelser, autoritet, vane og tradition osv. Sådanne alternativer mener jeg ikke er videnskabsteoretisk interessante at diskutere her. Hvis vi skal diskutere EBP må det være ud fra forskellige velbegrundede synspunkter om, hvad udtrykket "den bedste evidens" dækker over. Det kan i den forbindelse tilføjes, at videnskab ikke bør være sekterisk ${ }^{14}$ og prøve at forsvare sine interesser ved uakademiske metoder, herunder ved at tilskrive opponenter synspunkter, de ikke har, eller ved at argumentere ad hominem. Men en bevægelses relevans bør ikke bedømmes på, at der er i den også findes mere rabiate synspunkter, men på en nøgtern analyse af det bedste i bevægelsen sammenholdt med de bedste alternativer.

Det er jo faktisk kernen i erkendelsesteori og videnskabsteori at nå til klarhed over, hvad udtrykket "den bedste evidens" dækker over, eller med andre ord at belyse forskellige videnskabelige metoders styrker og svagheder i relation til at kunne fremskaffe den 
bedste evidens. Hvis man anerkender, at der eksisterer forskellige videnskabsteoretiske positioner ( $\mathrm{fx}$ positivisme, hermeneutik og kritisk teori), så betyder det, at disse positioner har forskellige metodeidealer, og at hvert af disse forskellige metodeidealer har sit bud på, hvordan man bedst fremskaffer den optimale videnskabelige evidens. Dvs. at diskussionen og kritikken af EBM/EBP må tage udgangspunkt i analysen af de forskellige metodeidealer, der er knyttet til forskellige videnskabsteoretiske positioner. Dette skulle være klart nok. Det svære ligger især i at afklare de forskellige positioner (jf. note $20 \mathrm{om}$ rehabilitering af positivisme). Det nytter imidlertid ikke at afvise problemet, fordi det er svært. Forskningens opgave er at løse problemer - ikke at gå uden om dem. Det er vigtigt med klarhed over, hvad der er hovedsynspunkterne i den videnskabsteoretiske debat. I denne forbindelse er en skematisk tilgang $\mathrm{i}$ mine øjne nødvendig. Hvis man skal nå til klarhed om forskellige positioner, må man stille dem klart op over for hinanden og undersøge deres antagelser ${ }^{15}$. En sådan skematisk modsætning må ikke forveksles med en teoretisk ensidighed, men ses som et forsøg på at skabe afklaring, og hermed som værende i modsætning til at bruge positioner som mudrede og tvivlsomme etiketter.

Cohen, Starvi \& Hersh (2004) grupperer kritikken af EBM i fem hovedtemaer (med referencer til nogle af de pågældende kritikere; i noteform har jeg tilføjet andre kritikere, der deler de pågældende synspunkter): "

1. EBM is based on empiricism, misunderstands or misrepresents the philosophy of science, and is a poor philosophic basis for medicine (Charlton \& Miles, 1998; Harari, 2001). ${ }^{16}$

2. The EBM definition of evidence is narrow and excludes information important to clinicians (Upshur, VanDenKerkhof \& Goel, 2001; Kenny, $1997^{17}$ ).

3. EBM is not evidence-based, that is, it does not meet its own empirical tests for efficacy (Haynes, 2002; Dobbie et al., 2000; Sehon \& Stanley, 2003).

4. The usefulness of applying EBM to individual patients is limited (Jones \& Sagar, 1995; Kenny, 1997; Naylor, 1995). ${ }^{18}$

5. EBM threatens the autonomy of the doctor/patient relationship (Hill, 2000; Charlton \& Miles, 1998; Kenny, 1997; Grahame-Smith, 1995).”
Disse punkter rummer jo en meget alvorlig kritik og afslører en dyb kontrovers i forhold til, hvordan man bedst fremskaffer og vurderer, hvad der er den bedste evidens. Vi skal ikke her behandle alle ovenstående kritikpunkter, men fokusere på de punkter, der er mest relevante for EBP i tværfaglig belysning, dvs. punkt 1-2, der dækker EBMs filosofiske grundlag og dens begreb om evidens.

Vi kan starte med at citere, hvad Kvale \& Brinkmann skriver ud fra et postmoderne perspektiv:

"A strict methodological positivist epistemology is rarely if ever advocated by philosophers of science today. Within the social sciences, however, the formal methodological rules of positivist science still prevail in certain places-in newer neopositivist positions, in many mainstream methodology textbooks, and in particular in the new discourse on evidence-based practice" (Kvale \& Brinkmann, 2009, side 58).

Vi kan vel tolke dette som et udtryk for, at forfatterne ser EBP som "positivistisk" og positivismen som forældet og problematisk. Dette svarer til kritikken af empiricismen i Cohen, Starvi \& Hersh (2004). Der er imidlertid mange uklarheder i videnskabsteorien, bl.a. om, hvad ordene "empirisme ${ }^{19}$ " og "positivisme $^{20 "}$ "står for, ligesom begreber som "evidens ${ }^{21}$ " og " EBM" også i sig selv er omdiskuteret ${ }^{22}$. Kvale \& Brinkmann (2009, side 57) beskriver, at samfundsvidenskabelige lærebøger fra 1950'erne (især i USA) blev domineret af en rigoristisk positivistisk epistemologi, der i deres udlægning bl.a. indebar et ideal om en generel forskningsmetode, der var uafhængig af det forskningsområde, den blev anvendt på samt et bureaukrati, der er karakteriseret ved standardiserede metoder og procedurer, regelmæssighed, formelle beslutningsregler, upersonlig upartiskhed, skriftlig kommunikation og kvantificering.

En tilsvarende analyse fremsættes af Olaf Rieper og Hanne Foss Hansen:

"Her viser det sig, at organisationernes retningslinier peger på, at de organisationer, der betoner evidenshierarkiet, anvender vurderingskriterier ud fra, hvad man kunne kalde et nypositivistisk paradigme med vægt på intern gyldighed. [...] Med hensyn til syntetisering af resultaterne anbefaler organisationer, der prioriterer RCT (som er toppen i evidens- 
hierarkiet) en metaanalyse som den ideelle metode. De andre organisationer har en pluralistisk tilgang til syntetisering og anbefaler også narrativ og konceptuel syntetisering afhængig af problemstillingen. "(Rieper \& Foss Hansen, 2007, side 9).

Her sættes altså forskellige opfattelser af, hvordan man bedst sammenfatter forskningsresultater og vurderer evidens, i relation til forskellige videnskabsteoretiske idealer. Vi vil uddybe kritikken af empiricismen/positivismen i næste afsnit ved at inddrage de vigtigste alternativer.

\section{Alternativer til empiricisme}

Kritisk teori

Ud fra et kritisk samfundsvidenskabeligt perspektiv kan det vække stor bekymring, at medicinsk forskning i højere og højere grad finansieres af medicinalindustrien, mens universitetsforskningen udhules. Dette er dog ikke i sig selv et argument imod EBM. Tværtimod har folk fra EBM bevægelsen ofte påpeget problemer ved medicinalindustriens reklamepåvirkning af læger, og anbefalet EBM som et alternativt, videnskabeligt baseret svar. Så i al fald på overfladen er EBM kritisk.

EBM er omkostningstung, og det betyder i praksis, at kun medicinalindustrien kan bære denne forskningsudgift, hvorfor man kan mene, at denne bevægelse er med til at svække den økonomisk uafhængige forskning. Dette er dog heller ikke et argument imod EBM som sådan, men kun et argument for en øget offentlig forskning i EBM. Den kritiske teori er baseret på den marxistiske tese, at teoriers sandhed skal vurderes i praksis. Umiddelbart vil tilhængerne af EBM vel sige, at dette er netop, hvad de medvirker til. En kritisk teoretisk kritik af EBM må derfor indebære en påvisning af, at dens resultater ikke er neutrale og ikke tjener patienternes, men industriens behov, dvs. problematisere evidensbegrebet i EBM. På dette punkt deler den kritiske teori synspunkter med visse andre videnskabsteoretiske positioner, som vi skal se nærmere på nedenfor. Der er dog måske to punkter, hvor den kritiske forskning kan siges at levere selvstændige argumenter:

1. I megen EBM sammenlignes effekten af en behandling ikke altid med det bedste alternativ men kun med en placebo-effekt. Det betyder, at patienter (eller samfundet) kan komme til at betale for udvikling af nye produkter, der ikke repræsenterer fremskridt, men som kun tjener industriens behov for nye patenter.

2. Kritisk teori interesserer sig for forholdet mellem forskning og samfund, herunder for spørgsmålet om, hvorvidt normerne for evidens fastsættes af et uafhængigt forskersamfund eller er under pres fra bureaukrater og andre eksterne interesser. Herunder hører spørgsmålet om EBP er et led i New Public Management (NPM) bevægelsen, og altså mere eller mindre er påtvunget forskersamfundet.

\section{Rationalisme}

Rationalisme er den klassiske modpol til empiris$m^{23}$. Det er en stærk og vigtig position, som ikke må undervurderes, selvom den umiddelbart virker uantagelig, fordi den jo er kritisk overfor erfaringsbaseret viden. Derfor er der også en tendens i den medicinske videnskabsteori til at undervurdere rationalismen. Djulbegovic, Guyatt \& Ashcroft (2009, side 160) vælger eksplicit ikke at diskutere rationalismen i relation til EBM. I deres "Glossary" (side 168) definerer de også empiricisme og rationalisme på måder, der gør det vanskeligt at tage rationalismen alvorligt i en moderne videnskabsteoretisk diskussion, fordi så godt som ingen i dag tror på videnskab uden empirisk forankring. ${ }^{24}$

Wulff, Pedersen \& Rosenberg (1990, side 15) definerer rationalismen som den epistemologiske position, der anerkender såvel sanseerfaring som tænkning som kilder til viden og kæder rationalismen sammen med realisme, der er synet på, at der eksisterer en bevidsthedsuafhængig verden. Den plads, som de skaber for rationalismen kalder de "realism under empirical control" (Ibid. side 32-33), og de daterer denne i medicinens historie i begyndelsen af det 19. århundrede ${ }^{25}$.

Min egen forståelse af denne problematik ligger nær op ad ovennævnte; dog vil jeg foretrække at sige, at jeg opfatter empiri og rationalitet som gensidigt betingede processer, der i et iterativt historisk forløb kan føre til stabile teorier og dermed til, hvad vi opfatter som den objektive realitet. I denne proces spiller pragmatiske faktorer også en rolle. Processerne er gensidigt betingede, fordi vores observationer (empiri) er teoriafhængige, og vores rationalitet er begrebsafhængig og under en vis "empirisk kontrol". 
Møhl \& la Cour (2008) behandler den historiske pendulering mellem empiricismen og rationalismen og skriver bl.a.:

\begin{abstract}
"I lægevidenskaben har man traditionelt skelnet mellem rationalister og empirister. Rationalisterne bruger deres viden om sygdomsmekanismer og -årsager til at beslutte, hvordan den enkelte patient skal behandles, mens empiristerne baserer deres beslutninger om behandling på tidligere erfaringer. EBM er et eksempel på empirisme, som der findes en meget lang tradition for helt tilbage fra omkring den franske revolution" (Møhl \& la Cour, 2008).
\end{abstract}

Som bekendt var det den engelske læge William Harvey (1578-1657), der først på korrekt og detaljeret måde beskrev hjertet og blodkarrene som et system. Ingen vil fraskrive dette som udtryk for empirisk forskning. Det er imidlertid samtidig et eksempel på en rationel model, hvoraf der kan udledes vigtige mulige konsekvenser, også selvom disse ikke (endnu) er empirisk bekræftede. Der er en vigtig forskel på at undersøge alle empiriske muligheder "i blinde" eller at gøre det ud fra rationalistiske antagelser om underliggende mekanismer. Begge muligheder anvendes i praksis. Medicinske forsøg, hvor man systematisk i troperne indsamler planter for at afprøve dem som medicin (inden de udryddes) hører nærmest til den empiristiske pol, mens afprøvning af medikamenter baseret fx på fysiologiske modeller hører mere til i den rationalistiske pol. Det synspunkt, at den empiristiske erkendelsesteori "har for lidt med i bagagen" blev allerede anerkendt af David Hume (1711-1776) og har givet anledning til skepticisme; det er samtidig det, der har sikret rationalismen vigtige modargumenter ${ }^{26}$. Det er tydeligt, at EBM/EBP hører til den empiristiske pol og derfor "har for lidt med i bagagen", selvom fortalere for denne strømning har forsøgt at undgå kritikken ved at gøre definitionen på EBM så bred, at det bliver uklart, hvorved den udgør et nyt paradigme.

Kombinationen af empiricisme og rationalisme (fx i logisk positivisme) har imidlertid også vist sig utilstrækkelig og problematisk. Det er først og fremmest fraværet af et historisk-kulturelt-socialt perspektiv for erkendelsens udvikling, der udgør problemet i disse to retninger både hver for sig og i kombination, hvilket jeg derfor vender mig imod nu.

\section{Historicisme}

Der er mange videnskabeteoretiske retninger i dag, der betoner erkendelsens sociale og historiske karakter. Hertil hører fx Thomas Kuhns (1922-1996) paradigmeteori, Hans-Georg Gadamers (1900 -2002) universelle hermeneutik, kritisk teori, psykologisk virksomhedsteori, pragmatismen, social konstruktivisme m.fl. Historicismen opfatter empiricismens og rationalismens individcentrerede redegørelser for erkendelsen som for snæversynede og problematiske, fordi de ikke medtænker betydningen af tradition og sociale fællesskaber for indlæring og begrebsdannelsen (jf. Flor, 2006, side 101). Det karakteriserer historicismen, at viden udvikles som en social dialog (eller måske rettere konflikt) mellem modsat rettede synspunkter og disses underliggende interesser. ${ }^{27}$

I relation til EBM kan historicismens kritik udfoldes som følger: EBM og dens fætter metaanalyser indsamler data fra tidligere publicerede undersøgelser på en mekanisk måde, der negligerer to ting: 1) at disse undersøgelser selv over tid udvikles teoretisk/begrebsmæssigt 2) at den enkelte undersøgelse altid er blevet udført på baggrund af en vis historisk/ kulturel/social forforståelse. Visse ældre videnskabelige undersøgelser ( $\mathrm{fx} \mathrm{RCTs}^{28}$ ) kan derfor ikke blot mekanisk behandles, som om de er udtryk for en nyere forståelse.

Tilsvarende kan undersøgelser, der er udført ud fra et bestemt teoretisk perspektiv ikke mekanisk sammenstilles med undersøgelser, der er anderledes informeret. Hvis man undersøger psykologiske studier af intelligens ( $\mathrm{fx}$ enæggede tvillinger opdraget i forskellige sociokulturelle miljøer) vil sådanne undersøgelser for det første tendere imod at negligere sociologiske undersøgelser af sproglige koders betydning for intelligensen (jf. Hjørland \& Nicolaisen, 2010), ligesom de næppe vil kunne sammenlignes af én metaanalyse. Det er med andre ord nødvendigt at kende de forskellige teorier, der er relevante for en problemstilling, og dette kræver en helt anden slags arbejde, der er meget mere i overensstemmelse med den hermeneutiske teori.

Når kompetente forskere i et domæne læser den videnskabelige litteratur, så fortolker de denne på en måde, der er forskellig fra metaanalysens mekaniske sammenstilling. De vurderer overordnet hver undersøgelses kvaliteter og tillægger den en vægt, der tager højde for langt flere forhold, herunder langt 
mere baggrundsviden om, hvad der karakteriserer god forskning ${ }^{29}$.

Der er endnu et kritikpunkt, der adskiller empirisme/ rationalisme på den ene side og historicisme på den anden. Det vedrører den berømte distinktion imellem opfindelseslogik og verifikationslogik ("context of discovery and context of justification", jf. Hoyningen-Huene, 1987 og 2006). Testningen af fx farmaci bliver i den positivistiske filosofi tænkt som en objektiv test (med RCT som den gyldne standard), der er uafhængig af de medicinske teorier, der styrer opdagelsen af disse farmaci. Det er i imidlertid i sagens natur er begrænset, hvor mange forsøg, man kan udføre $^{30}$. I praksis vil eksperimenterne derfor altid bygge på en udvælgelse af hypoteser om, hvad der er værd at teste. Og disse hypoteser bør være styret af den bedste medicinske teori, men dette er i sagens natur subjektivt. Hvis man fx opfatter stress som årsag til mavesår - hvad man gjorde frem til $2005^{31}$, så afprøver man syreneutraliserende og afstressende medikamenter, og ikke bakteriebekæmpende medicin. Der kan være læger, patienter eller alternative behandlere, der tidligere er kommet på sporet af den helbredende virkning af bakteriedræbende medicin, men denne viden vil stå meget svagt indtil der kan skaffes midler til de meget kostbare undersøgelser, der lever op til EBM-normerne.

Det er generelt for de retninger, som vi har sammenfattet under etiketten "historicisme", at de - i modsætning til empirisme og rationalisme - lægger megen vægt på teoriers rolle i videnskaben (herunder baggrundsteoriers og paradigmers rolle), hvad enten det drejer sig om opdagelser eller underbygning af påstande.

\section{Andre kritikpunkter}

Når EBM taler om "best evidence", så refereres der til et hierarki af kilder til at opnå klinisk viden - der er bedst evidens i toppen og værst i bunden. Dette hierarki kan fx se således ud:

"l a Evidence from a meta-analysis of RCTs [randomized controlled trials]

$l \mathrm{~b}$ Evidence from at least one RCT

ll a Evidence from at least one controlled study without randomisation

$l l b$ Evidence from at least one other type of quasiexperimental study lll Evidence from non-experimental descriptive studies, such as comparative studies, correlation studies and case-control studies

$l V$ Evidence from expert committee reports, or opinions and/or clinical experience of respected authorities" (Geddes \& Harrison, 1997).

Møhl \& la Cour (2008) skriver: "Problemet er, at denne hierarkiske liste præsenteres som om den skulle have generel gyldighed - dvs. gælde uanset, hvilket klinisk problem man ønsker at undersøge". De fremhæver at især inden for psykologi er denne rangordning problematisk. Også informationsforskeren Olof Sundin kritiserer dette:

"Within the evidence-based movement, especially evidence-based medicine, a hierarchy of scientific methods has been established in order to evaluate the "veracity" of research findings. This hierarchy can differ in details, but at the top is Randomized Controlled Trials (RCT), or compilations of such, and at the bottom are case studies and qualitative research. Since medical knowledge has precedence in healthcare, other professions interested in the evidence-based movement have had to relate to this hierarchy. Problems occur-depending on how strictly the hierarchy of evidence is followedin the meeting between evidence-based medicine and the often qualitative human sciences oriented nursing research of today (cf. Willman \& Stoltz, 2002). It can be maintained that the methods of the evidence-based movements have a specific in-built epistemology and that it is therefore problematic to transmit the ambitions of the movement from medicine to nursing. The above described hierarchy of evidence has thus partly challenged qualitative nursing research whose findings by definition always end up furthest down in the hierarchy." (Sundin, 2003).

Et andet kritikpunkt, som Møhl \& la Cour (2008) rejser er, at lægens spørgsmål skal være "an answerable question":

"Der skal ikke stilles spørgsmål om noget, som ikke er blevet dokumenteret af RCT studier og hermed er der lagt op til kogebogsmedicin ${ }^{32}$, hvor man kan finde svar på alt $\mathrm{i}$ en autoritativ opslagsbog (læs: Cochrane review eller behandlingsvejledning). Det, man ikke kan finde svar på "fordi 
det ikke passer ind i løsningerne”, skal man ifølge EBM logikken ikke spørge om!"

\section{Diskussion}

EBM/EBP repræsenterer en betydelig opstramning af den videnskabelige dokumentation til brug for beslutningsprocesser i medicin og andre felter. Den prioriterer klart hvilken slags undersøgelser, der må anses som væsentlige for etablering af et beslutningsgrundlag. Som sådan repræsenterer EBM/EBP en vigtig strømning.

Indbygget $\mathrm{i}$ disse bestræbelser ligger imidlertid et dilemma og en modsætning. På den ene side vil man gerne formalisere og standardisere forskningen og dens dokumentation. Processen gøres meget mekanisk (kogebogsagtig), fordi dette hænger sammen med bagvedliggende idealer om kontrol og objektivitet. Selve forskningens (såvel som praksis) natur lader sig imidlertid ikke sætte på en formel eller en algoritme. EBP kommer herved i modsætning til videnskabsteoretiske opfattelser, der lægger vægt på fortolkning knyttet til de historicistiske normer. EBM var tænkt som en øget prioritering af kliniske eksperimenter på bekostning af dels den enkelte klinikers erfaringer, dels af den teoretiske forståelse af fx fysiologiske mekanismer. Men hvor meget skal disse ting nedprioriteres? EBM bygger ikke på noget empirisk basis for, hvor denne balance skal gå (jf. Jones \& Sagar, 1995) ${ }^{33}$.

Hvis medicinsk forskning helt overtages af EBM, så udtørres grundforskningen, og grundlaget for videnskabelige kvantespring (jf. note 26 om at forbedre stearinlyset frem for at opdage elektriciteten). Tilhængerne kan så indvende, at EBM/EBP blot skal være et ekstra lag af anvendt videnskab, der ligger oven på grundforskningen. I så fald er der imidlertid brug for en overordnet videnskabsteoretisk ramme, der regulerer dette forhold, og som indebærer et større indslag af fortolkning. Såfremt man også mener, at praktikere har brug for den indsigt, der ligger i grundforskningen, så svækkes det mekaniske moment og dermed EBP-filosofien igen.

Især Rieper \& Foss Hansens (2007) fremragende belysning har bekræftet mit eget syn, at forskellige videnskabsteoretiske opfattelser implicerer forskellige idealer at udvælge evidens og syntetisere denne.
Nogle tilgange er nypositivistiske, andre er mere hermeneutiske og endelig er nogle kritisk realistiske ${ }^{34}$ og baseret på en dybere forståelse af den underliggende kausalitet i genstandsfeltet. Konsekvensen af dette er, at man ikke kan diskutere evidensbaseret praksis uden at diskutere videnskabsteori, og at et givent syn på EBP må forsvares videnskabsteoretisk.

\section{Konklusion}

Jeg spurgte indledningsvis, hvad EBM er alternativ til. Hovedsvaret er, at EBM især er i modsætning til en teoretisk forståelse af medicin, fysiologi og sygdomsmekanismer såvel $i$ et rationalistisk som i et teorihistorisk perspektiv. EBM repræsenterer først og fremmest en empiristisk svingning af en pendulerende videnskabsteoretisk tendens. Som sådan har EBM arvet alle de svagheder, som følger med empiricismen, og som er velbeskrevne i den videnskabsteoretiske litteratur. Hvis man vil argumentere for, at EBM tillader kliniske vurderinger, rationalistiske modeller og teorihistoriske perspektiveringer, så forsvinder bevægelsens særpræg og begrebet bliver udvandet. Givet denne ensidighed knyttet til termen EBM (og EBP) ville det være bedre at tale om forskningsbaseret praksis, fordi der ikke til denne term knytter sig en videnskabsteoretisk ensidighed.

BDI-specialister kan arbejde i mange forskellige domæner, og jeg har gennem en årrække beskæftiget mig med det teoretiske grundlag for sådant arbejde under betegnelsen "domæneanalyse". Jeg synes det er åbenlyst, at BDI-personer, der arbejder inden for medicin skal besidde en dybtgående viden om principperne for EMB. Det er også vigtigt, at de ved, at der findes andre "paradigmer", der er kritiske overfor EBMs krav, og som derfor stiller andre krav til medicinsk dokumentation. Denne viden kan til dels generaliseres til andre fag, fordi de ensartede videnskabsteoretiske positioner kan spores i så godt som alle fag. Det gælder for alle forskere (og altså også BDIforskere), at de må udvikle selvstændige holdninger til de fænomener, de beskæftiger sig med.

Den videnskabsteoretiske kritik præsenteret i denne artikel rammer således alle andre former for EBP, herunder evidensbaseret biblioteks- og informationsvidenskab. EBP er for snæver, formalistisk og mekanisk en tilgang til videnskabelig dokumentation. Der er behov en bredere funderet videnskabsopfattelse 
også i relation til alle processer vedrørende videnskabelig dokumentation.

\section{Noter}

1. Dette er en dansk version af en artikel, der er accepteret og under udgivelse af Journal of the American Society for Information Science and Technology. Det er fra Dansk Biblioteksforsknings side accepteret at copyrighten overgår til JASIST hermed.

2. Evidensbevægelsens historie og organisatoriske forankring er beskrevet i Bhatti. Hansen \& Rieper (2006). Inden for BDI se fx Urquhart (2010).

3. Se fx Hjørland (2005) for en til dels tilsvarende kritik, der fokuserer på Biblioteks- og Informationsvidenskab.

4. Hvorvidt EBM udgør et "paradigme" i Kuhn's (1962) forstand skal ikke drøftes i denne artikel, det kan blot fastslås at bevægelsen ofte beskrives som et nyt paradigme. Evidence-based medicine working group (1992) skrev således "A new paradigm for medical practice is emerging". Sehon \& Stanley (2003) argumenterer derimod for ikke at betragte EBM som et paradigmeskift.

5. Kumar (2000) kalder EBM "the new paradigm of clinical decision making" og modstiller det "Opinion Based Medicine or The Old Paradigm”. Dette udgør i mine øjne en for stærk nedvurdering af medicinsk praksis før EBM.

6. The Cochrane Handbook for Systematic Reviews of Interventions (Higgins \& Green, 2009) anbefaler også, at upublicerede undersøgelser og igangværende forskning inddrages.

7. Dette metaniveau udgør jo det centrale genstandsfelt for BDI. Det er det vi er eller bør være eksperter i. I al fald de af os, der har relation til forskningsbiblioteksvæsnet.

8. Systematiske reviews er forskningsoversigter, der syntetiserer viden fra multiple primærstudier. Med andre ord er filosofien og metoderne bag udarbejdelsen af systematiske reviews en kerneaktivitet i EBM.
9. Empiricisme må ikke forveksles med empirisk forskning. Der er vel ingen seriøse forskere, der kan bestride, at medicinsk forskning skal være empirisk. Metodeidealer handler derfor om på hvilken måde denne empiriske forskning bør bedrives, og her udgør empiricisme en klassisk position, der i dag anfægtes af andre positioner. Dette vil blive taget op senere i denne artikel.

10. Det er bemærkelsesværdigt, at hvor det brugerorienterede paradigme i LIS har brugernes præferencer som højeste prioritet, så ligger de som regel i bunden af evidenshierarkiet i EBP.

11. Fx genreanalyse, jf. Andersen (2008).

12. Det er ligeledes forbløffende, at de mange BDIforskere, der har arbejdet med informationssøgning i så vid udstrækning har negligeret de helt centrale spørgsmål, som EBP har rejst, dvs. perspektivet om, hvorvidt forskellige søgestrategier formår at indfange de dokumenter, der er centrale ud fra en videnskabelig argumentation.

13. Dette bud er i øvrigt ikke så satirisk, som det umiddelbart kan lyde. Fremkomsten af Internettet har gjort mange patienter bedre informeret og dermed i stand til at give lægerne et bedre modspil.

14. For en kritik af sekteriske tendenser i EBM se fx Charlton \& Miles (1998), der også påpeger indflydelse, der ikke kommer fra videnskaben, men fra administrativt og politisk hold.

15. Bemærk at det er teoretiske (ideelle) positioner, man stiller op over for hinanden - ikke personer (der måske benytter etiketten "evidensbaseret" på en mere kompromissøgende facon).

16. Også Whitre \& Willis (2002) kan medtages under dette punkt.

17. Også Henry, Zaner \& Dittus (2007) kan medtages under dette punkt.

18. Også Tonelli (1998) kan medtages under dette punkt.

19. Se fx Van Fraassen (2004). 
20. Kvale \& Brinkmann (2009, side 56-57) skriver selv, at den klassiske positivisme er misforstået og bør rehabiliteres, idet de mener, at problemerne ligger i påvirkningen fra den logiske positivisme fra 1920'erne. Også den logiske positivisme er imidlertid delvis blevet rehabiliteret. Reisch (2005) argumenterer fx for, at den logiske positivisme (eller, som den også kaldes: den logiske empirisme) i 1930'erne var om ikke marxistisk, da stærkt venstreorienteret; i 1950'erne havde den kolde krigs antikommunisme (McCarthyisme) i USA imidlertid bevirket, at alle spørgsmål om værdier og interesser blev isoleret fra videnskabsteoretiske normer og derfor havde transformeret den logiske positivisme til "the icy slopes of logic". Det var med andre ord mere af nødvendighed for egen sikkerhed end af teoretiske grunde, at de logiske positivister udviklede sig som de gjorde, og i dag - da den kolde krigs påvirkning er glemt - stadig fremstår i lyset fra 1950’erne.

21. Mandag Morgen (2004, side 12) skriver: "At arbejde evidensbaseret vil sige: Omhyggelig, udtrykkelig og kritisk brug af den bedste viden i forbindelse med beslutninger [...]. Bedste aktuelle viden - er viden, der er organiseret efter graden af evidens". Der henvises her til evidensstigen/evidenshierarkiet. Det er imidlertid den generelle antagelse om et evidenshierarki, der er til videnskabsteoretisk debat.

22. Sehon \& Stanley (2003) skriver:" the proponents of EBM come awfully close to simply defining EBM as the best way to practice medicine, whatever that may be. In other words, they respond to the second order conceptual question ("what is EBM?") by saying that EBM is whatever approach to medicine best answers the first order normative question ("how ought we to practice medicine?"). The proponents of EBM thereby give the illusion of having answered both sets of questions when in fact they have answered neither. They thus walk away from an important and substantive debate.

23. Klassifikationen empiricister versus rationalister er kritisk behandlet af Markie (1998).

24. Richards (2010, side 399):"Rationalism. The opposite of empiricism: the philosophical doctrine that there are certain innate principles which determinate our knowledge and that knowledge can be acquired by pure reasoning according to objectively existing but innately known (or knowable) principles of logic. Like empiricism this has actually come in a variety of forms. Few, if any, contemporary philosophers would espouse rationalism in anything like its original eighteenth-century senses, and the polarity is to a large extent obsolete in the wake of twentieth-century logical positivism, linguistic philosophy and social constructionist epistemologies".

25. Den rene rationalisme beskriver Wulff, Pedersen \& Rosenberg (1990, side 31-33) nærmest som en slags skrivebordsforskning, der udgør et overvundet stadium i medicinens historie.

26. Lidt karikeret kan man måske sige at hvis fysikeren H.C. Ørsted havde været henvist alene til empiricistiske principper, så havde han blot kunnet forbedre stearin-lyset i stedet for at opfinde elektriciteten!

27. Sådanne historicistiske retninger begynder også at få indflydelse i medicin. Det vil her føre for vidt at give en oversigt. Nogle få eksempler skal dog nævnes her: Cooper (1994) argumenterer for hermeneutikken, mens Wilson (2000) argumenterer for socialkonstruktivismen. Fleck $(1935 ; 1979)$ er en vigtig bog om medicinsk videnskabsteori, der i dag ses som en forløber for Kuhn (1962).

28. RCT kaldes på dansk lodtrækningsforsøg eller randomiseret undersøgelse. Disse er blevet betegnet "the gold standard of efficacy determination" (en betegnelse, der kritiseres af Ashcroft, 2004). Det er vigtigt at fremhæve at kritikken af EBM ikke primært har stillet spørgsmålstegn ved værdien af sådanne eksperimenter (selvom disse også har deres kritikere, jf. Aschroft, 2004; Scocozza (2000). Det er primært den relative fortolkning af disse eksperimenters rolle, der kritiseres. Der er en meget dybtgående behandling af problematikken i Rieper \& Foss-Hansen (2007), der konkluderer: "Det bemærkes, at et stridsspørgsmål er, under hvilke omstændigheder et veldesignet og gennemført RCT i det hele taget vil give gyldig og anvendbar viden" (side 77). 
29. Boffetta et al. (2008) argumenterer på en særdeles overbevisende måde for "epistemologisk beskedenhed" og kan stærkt anbefales som demonstration af hvordan kvalificeret "læsning" af medicinsk viden kan tage sig ud.

30. RCTs er i praksis meget kostbare, men dette er ikke principielt afgørende: Det vil altid være begrænset, hvor mange hypoteser, der kan testes, da det er meget letter at få en ide, end at undersøge om den er noget værd.

31. I 2005 modtog Dr. Marshall og Dr. Warren Nobelprisen i medicin for at have påvist, at mavesår i vidt omfang er forårsaget af bakterien Helicobacter pylori. Før da blev det anses som umuligt, at bakterier kunne leve i så stærk syre. Opdagelsen betragtes som et "paradigmeskifte" i forståelsen og behandlingen af denne sygdom.

32. Om EBM og kogebogsmedicin se også Juul Jen$\operatorname{sen}(2004)$.

33. Det er i øvrigt et filosofisk paradoks, at empirismens begrundelse ikke kan gives empirisk, men bygger på et rationalistisk fundament, hvilket er en logisk underminering af empiricismen. På samme måde forholder det sig med EBP.

34. Pawson (2006) er hovedbidraget om EBP set fra et kritisk-realistisk perspektiv og hans bog rummer en hård kritik af de dominerende opfattelser, som disse praktiseres i fx Cochrane- og Campbell organisationerne.

\section{Referencer}

Andersen, J (2008). The concept of genre in information studies. Annual review of Information Science and Technology, 42, 339-367.

Ashcroft, RE (2004). Current epistemological problems in evidence based medicine. Journal of Medical Ethics, 30(2), 131-135. Hentet 2010-09$08 \mathrm{fra} \mathrm{http://www.ncbi.nlm.nih.gov/pmc/articles/}$ PMC1733829/pdf/v030p00131.pdf

Bhatti, Y; Foss Hansen, H \& Rieper, O (2006). Evidensbevagelsens udvikling, organisering og arbejdsform. En kortloegningsrapport. København: AKF forlaget. Hentet 2010-09-13 fra: http://www.akf.dk/ udgivelser/2006/pdf/evidens.pdf

Boffetta, P et al. (2008). False-Positive Results in Cancer Epidemiology: A Plea for Epistemological Modesty. Journal of the National Cancer Institute, 100(14), 988-995. Hentet 2010-09-03 fra: http://jnci. oxfordjournals.org/cgi/reprint/100/14/988

Carter, MJ (2010). Evidence-based Medicine: An Overview of Key Concepts. Ostomy Wound Management, 56(4), 68- 85. Hentet 2010-09-03 fra: http:// www.o-wm.com/content/evidence-based-medicinean-overview-key-concepts

Charlton, BG \& Miles, A (1998). The rise and fall of EBM. Quarterly Journal of Medicine, 91(5), 371374. Hentet 2010-09-03 fra: http://qjmed.oxfordjournals.org/content/91/5/371.full.pdf + html

Clinicians for the Restoration of Autonomous Practice (CRAP) Writing Group (2002). EBM: unmasking the ugly truth. British Medical Journal, 325(7378), 1496-1498. Hentet 2010-09-03 fra: http://www.ncbi. nlm.nih.gov/pmc/articles/PMC139053/

Cochrane, AL (1972). Effectiveness and Efficiency. Random Reflections on Health Services. London: Nuffield Provincial Hospitals Trust.

Cohen, AM, Starvi, PZ, \& Hersh, WR (2004). A categorization and analysis of the criticisms of Evidence-Based Medicine. International Journal of Medical Informatics, 73(1), 35-43.

Cooper, MW (1994). Is medicine hermeneutics all the way down? Theoretical Medicine and Bioethics, 15(2), 149-180.

Djulbegovic, B; Guyatt, GH \& Ashcroft, RE (2009). Epistemologic Inquiries in Evidence-Based Medicine. Cancer Control, 16(2), 158-168. Hentet 201009-03 fra: http://www.moffitt.org/CCJRoot/v16n2/ pdf/158.pdf

Dobbie, AE et al. (2000). What evidence supports teaching evidence-based medicine? Academic Medicine, 75(12), 1184-1185.

Evidence-based medicine working group (1992). Evidence-based medicine: A new approach to tea- 
ching the practice of medicine. JAMA [The Journal of the American Medical Association], 268(17), 2420-2425.

Fleck, L (1979). Genesis and Development of a Scientific Fact. Chicago: University of Chicago Press. (German original 1935).

Flor, JR (2006). Erkendelsesteori. Introduktion til filosofi. København: Museum Tusculanums Forlag.

Geddes, JR \& Harrison, PJ (1997). Evidence-based psychiatry: closing the gap between research and practice. British Journal of Psychiatry, 171(9), 220225.

Grahame-Smith, D (1995). Evidence-Based Medicine: Socratic dissent. British Medical Journal, 310(6987), 1126-1127.

Harari, E (2001). Whose evidence? Lessons from the philosophy of science and the epistemology of medicine. Australian and New Zealand Journal of Psychiatry, 35(6), 724-730.

Haynes, RB (2002). What kind of evidence is it that Evidence-Based Medicine advocates want health care providers and consumers to pay attention to? BMC Health Services Research, 2(1), 3.

Henry, SG, Zaner, RM \& Dittus, RS (2007). Viewpoint: Moving Beyond Evidence-Based Medicine. Academic Medicine, 82(3), 292-297. Hentet 201009-03 fra: http://journals.lww.com/academicmedicine/Fulltext/2007/03000/Viewpoint_Moving_Beyond_Evidence_Based_Medicine.15.aspx

Higgins, JPT \& Green, S (eds.) (2009). The Cochrane Handbook for Systematic Reviews of Interventions, version 5.0.2. London: The Cochrane Collaboration. Hentet 2009-10-22 fra: http://www. cochrane-handbook.org/

Hill, GB (2000). Archie Cochrane and his legacy. An internal challenge to physicians' autonomy? The Journal of Clinical Epidemiology, 53(12), 11891892.

Hjørland, B (2000). Hvad blev der af videnskabelig dokumentation? DF-revy, 23(7), 191-194. Hentet 2010-09-07 fra: http://www.db.dk/binaries/hvad\%2 0blev\%20der\%20af\%20videnskabelig\%20dokumen tation.pdf

Hjørland, B (2005). Empiricism, rationalism and positivism in library and information science. Journal of Documentation, 61(1), 130-155.

Hjørland, B (2010). The foundation of the concept of relevance. Journal of the American Society for Information Science and Technology, 61(2), 217-237.

Hjørland. B \& Nicolaisen, J (2010). The Social Psychology of Information Use: Seeking "Friends", Avoiding "Enemies". Paper presented at the 7th CoLIS conference in London, on the 23rd of June 2010. Information Research, 15(3). Hentet 2010-09-14 fra: http://informationr.net/ir/15-3/colis7/colis706.html

Hoyningen-Huene, P (1987). Context of discovery and context of justification. Studies in History and Philosophy of Science, 18, 501-515. Hentet 2010-09-15 fra: http://www.zeww.uni-hannover. de/019_Hoyningen_ctxt_disc.pdf

Hoyningen-Huene, P (2006). Context of discovery versus context of justification and Thomas Kuhn. I: J. Schickore and F. Steinle (eds.), Revisiting Discovery and Justification, 119-131. Berlin: Springer. Hentet 2010-09-15 fra: http://www.psiquadrat.de/ downloads/hoyningen-huene2006.pdf

Jones, GW \& Sagar, SM (1995). Evidence-Based Medicine. No guidance is provided for situations for which evidence is lacking. British Medical Journal, 311(6999), 258-259.

Juul Jensen, U (2004). Evidens, viden og sundhedsfaglig praksis i filosofisk perspektiv - eller faren ved at være mere katolsk end paven. I: JJ Bruun, ML Hanak \& BG Kofoed (red), Viden og Evidens $i$ Forebyggelsen. København: Sundhedsstyrelsen (s. 1929). Hentet 2010-09-07 fra: http://www.sst.dk/publ/ publ2004/evidensviden.pdf

Kenny, NP (1997). Does good science make good medicine? Incorporating evidence into practice is complicated by the fact that clinical practice is as much art as science. Canadian Medical Association Journal, 157(1), 33-36. 
Kuhn, TS (1962, 1970, 1996). The Structure of Scientific Revolutions, University of Chicago Press, Chicago, IL.

Kumar, S (2000). Evidence-based medicine: The new paradigm of clinical decision making. Indian Journal of Urology [serial online], 17(1), 73-78. Hentet 2010-09-03 fra: http:/www.indianjurol.com/ text.asp?2000/17/1/73/41030

Kvale, S \& Brinkmann, S (2009). Interviews: Learning the Craft of Qualitative Research. 2nd Edition. Thousand Oaks, CA: Sage Publications.

Mandag Morgen (2004). Virker velfcerden? Et debatoplceg om evidens og velfcerd. København: Mandag Morgen. Hentet 2020-09-13 fra: https://www.mm.dk/ pdf.php?id=35690

Markie, PJ (1998). Rationalism. IN: Edward Craig (editor): The Routledge encyclopaedia of philosophy, volume 8, London: Routledge, 75-80.

Møhl, B \& la Cour, P (2008). Nogle kritiske vinkler på EBM - logikken. Psykologiteoretisk arbejde. Psyke og Logos, 29(1), 126-151. Hentet 2010-09-03 fra: http://peterlacour.dk/index-filer/ Kritisk\%20om\%20EBM.doc

Naylor, CD (1995). Grey zones of clinical practice: some limits to Evidence-Based Medicine, Lancet, 345(8953), 840-842.

Pawson, R (2006) Evidence-based Policy. A Realist Perspective, London: Sage.

Reisch, GA (2005). How the cold war transformed philosophy of science: To the Icy Slopes of Logic. Cambridge: Cambridge University Press.

Richards, G (2010). Putting psychology in its place. Critical historical perspectives. Third edition. London: Routledge.

Rieper, O \& Foss Hansen, H (2007). Metodedebatten om evidens. København: AKF forlaget. Hentet 201009-13 fra: http://www.akf.dk/udgivelser/2007/pdf/ metodedebat_evidens.pdf
Scocozza, L (2000). The randomised trial. A critique from the philosophy of science. I: Gannik, Dorte E. og Laila Launsø (eds.) Disease, knowledge and society (s. 231-242). Samfundslitteratur: Frederiksberg.

Sehon, SR \& Stanley, DE (2003). A philosophical analysis of the evidence-based medicine debate. Published: BMC Health Services Research, 3(1), 14. Hentet 2010-09-03 fra: http://ukpmc.ac.uk/backend/ ptpmcrender.cgi?accid=PMC169187\&blobtype=pdf

Sundin, O (2003). Towards an understanding of symbolic aspects of professional information: an analysis of the nursing knowledge domain. Knowledge Organization, 30(3/4), 170-181.

Tonelli, MR (1998).The philosophical limits of evidence-based medicine. Academic Medicine, 73(12), 1234-1240.

Upshur, RE, VanDenKerkhof, EG \& Goel, V (2001). Meaning and measurement: an inclusive model of evidence in health care. Journal of Evaluation in Clinical Practice, 7(2), 91-96.

Urquhart, C (2010). Systematic reviewing, meta-analysis and meta-synthesis for evidence-based library and information science. Information Research, 15(3) colis708. Hentet 2010-09-14 fra: http://InformationR.net/ir/15-3/colis 7/colis708.html

Van Fraassen, BC (2004). The Empirical Stance. New Haven, CT: Yale University Press.

Whitre, K \& Willis, E (2002). Positivism resurgent the epistemological foundations of evidence based medicine. Health Sociology Review, 11(1/2), 5-15.

Wilson, HJ (2000). The myth of objectivity: is medicine moving towards a social constructivist medical paradigm? Family Practice, 17(2), 203-209. Hentet 2010-09-08 fra: http://fampra.oxfordjournals.org/ content/17/2/203.full.pdf

Wulff, HR, Pedersen, SA \& Rosenberg, R (1990). Philosophy of Medicine. An Introduction. 2.ed. Oxford: Blackwell Scientific Publications. 